\title{
Knowledge, Attitude, Practices and Associated Factors Towards Colostrum Feeding among Mothers of Infants in Ambo District of West Shewa Zone, Oromiya Region, Ethiopia
}

Jiregna Darega Gela ( $\nabla_{\text {jiregnadarega@yahoo.com })}$

Ambo University College of Medicine and Public Health

Dereje Minase

West Shewa Department of Health

Elias Teferi

Ambo University College of Medicine and Public Health

Tamiru Tesfaye

Ambo University

Research

Keywords: Ambo, attitude, colostrum feeding, Ethiopia, knowledge, practice, west Shoa

Posted Date: October 9th, 2020

DOI: https://doi.org/10.21203/rs.3.rs-87805/v1

License: (c) (1) This work is licensed under a Creative Commons Attribution 4.0 International License.

Read Full License 


\section{Abstract}

Background: Colostrum is the first breast milk produced after birth and is important for promotion of health and prevention of infections of the newborn. Though breastfeeding practices are well known but the necessity of colostrum feeding is still poorly understood by mothers.

Objective: To assess Knowledge, Attitude, Practices and associated factors towards colostrum feeding among mothers of infants in ambo district of west Shoa zone, Oromia, Ethiopia.

Methods: A community-based cross-sectional study was conducted from March to April 2019 among 429 mothers of infants selected by simple random sampling technique. The data were collected using structured questionnaire, focus group discussion \& key informant interview by semi structured guiding questionnaire. Descriptive analysis like frequency, percentage, \& mean were performed. Binary and multiple logistic regression analysis were employed to identify associated factors. Variables with p-value $<0.05$ with $95 \%$ confidence interval identified statistically significant.

Results: Among the respondents, 278 (64.8\%) mothers had good knowledge \& 250 (58\%) had favorable attitude. But colostrum feeding was practiced only by $227(56.5 \%)$. Mothers of neonates without any illness/finding at birth (AOR $=14.87$ [ $95 \% \mathrm{Cl}: 5.00-44.27])$ \& postnatal care within the first 2-3 days (AOR = 3.48 [95\% Cl: 1.23-9.85]) were positively associated factors; but unwanted pregnancy/birth (AOR $=0.243$ [95\% Cl: .113-.527]), mothers suffering from any health problems during pregnancy/birth (AOR $=0.380$ [95\% Cl: .161-.903]), lack of counseling (AOR $=0.264$ [95\% Cl: .103-.675]), home delivery (AOR $=0.239$ [95\% Cl: .111-.516]), \& lack of information on colostrum (AOR $=0.040$ [95\% Cl: .013-.125]) were negatively associated with colostrum feeding practices.

Conclusions: Majority of respondents had good knowledge \& favorable attitude but with poor practices of colostrum feeding. Good neonatal health at/soon after birth \& postnatal care attendance within two to three days were positively associated with colostrum feeding practices. But, unwanted pregnancy/birth, any sickness of mother at birth/during pregnancy, lack of counseling on colostrum feeding, home delivery, \& lack of information on colostrum feeding were less likely to feed colostrum.

Strengthening family planning service, antenatal care, institutional delivery, postnatal care, information provision for counseling \& the revision of $\mathrm{DHIS}_{2}$ for inclusion of colostrum feeding indicators were recommended interventions.

\section{Background}

Colostrum is the first milk lasting for 2-4 days after the lactation is started, secreted at the time of parturition. It differs from the milk secreted later by containing more lactalbumin, lacto protein, \& rich in antibodies that confer passive immunity to the newborn. Colostrum, which, is very important component of the breast milk and it has role to play in immune system of every mammal. Human colostrum is particularly rich in immunoglobulin, antimicrobial peptides (lactoferrin and lacto-peroxidase) and other 
bioactive molecule, including growth factors which are important for nutrition, growth and development of infants. It is highly concentrated in very less volume of 30-100 ml. It is gold/bright yellow in color, thick, and sticky consistency (1).

Colostrum acts as a primer for breast milk, leading pediatric nutrition specialists refer to it as "liquid gold". It can be also considered as the first vaccine which needs a "warm chain" made by mother-infant contact(2). It establishes important bacteria in the baby's gut and also acts as 'paint', coating the infant's gastrointestinal tract. Therefore, colostrum provides natural immunity against many bacteria and viruses (3). Passing immunity to a wide variety of disease-causing pathogens for protection from bacteria, viruses, fungi, and even protozoan parasites like giardia. Not even antibiotics can deliver such broadspectrum protection. Moreover, pathogens do not develop resistance to colostrum as they do to manmade antibiotics. It also provides good growth, strength and longevity for the infant (4).

The World Health Organization recommends breastfeeding within the first hour to three days after birth. In addition to colostrum feeding, early initiation of breastfeeding can enhance exclusive subsequent breastfeeding and mother-infant bonding. Many perinatal deaths are potentially preventable if newborns are breastfed within one hour to three days of birth. Breast milk should be made a baby's first taste within an hour, hence any pre-lacteal feeds should be avoided (2).

How soon woman begin breastfeeding after birth is also culturally determined. Many cultural beliefs and practices may make mothers not to feed the baby immediately after birth (5). Some mothers in developing countries avoid colostrum feeding on the basis of traditional or cultural beliefs that range from having no nutritional value and viewing as harmful to the infant's health making the baby sick or even causing death (6). Even, some women may specify no reason for avoiding colostrum other than tradition (7). Especially in non-industrialized populations, initiation of colostrum feeding within an hour is thought to decrease infant mortality from the risks of gastroenteritis, diarrheal diseases, respiratory infections, ear infections, and influenza (8). In societies where colostrum is considered heavy, thick, dirty, toxic, harmful to children's health, \& believe to cause diseases, it is believed that discarding a portion of it can alleviate the problems(9).

The National Newborn and Child Survival Strategy (2015/16-2019/20), which is part of the HSTP covering same period, aims to reduce under five mortality from 64/1,000 live births (2013 level) to $29 / 1,000$ live births, infant mortality rate from 44/1000 live births to 20/1000 live births and NMR from $28 / 1,000$ live births to $11 / 1,000$ live births. The strategy plans to ensure universal coverage of quality high impact newborn and child health interventions like early initiation of breast/colostrum feeding within an hour along with meaningful community empowerment to create demand for the services(10).

Colostrum feeding was recommended in the Ethiopian Infant and Young Child Feeding Guideline. However, colostrum avoidance is still practiced in many parts of Ethiopia including Oromiya regional state. Moreover, there is a scantiness of evidence regarding knowledge, attitude, practices, and associated factors towards colostrum feeding practices among mothers in Oromiya region, chiefly in Ambo district. This study will help to know the concept of colostrum among the general population. It also helps the 
community to create awareness about the importance of colostrum feeding and advise mothers to practice it in every delivery. Appreciate and initiate counselling methods to reinforce specific, priority messages by health facility staff and community-based workers at all contact points with women. Hence, this study aimed to investigate KAP \& associated factors towards colostrum feeding practices among mothers of infants in Ambo district, central-west Ethiopia(11).

\section{Methods}

\section{Study area \& period}

The study was conducted in Ambo district from March 1 to April 7/2019. Ambo is one of the districts of west Shoa zone in Oromia Region of Ethiopia. It is located at $114 \mathrm{~km}$ west to Finfinee/Addis Ababa on the main road to Wollega. Bordered by T/kutaye to west, by Cobi and Ilfeta to north, by Dendi to east, by Wonchi district of Southwest Shewa Zone to south. Based on the information from Ambo district administration health office, the district has 32 rural and 1 urban totally of 33 "Gandas" (small administration units). The district has six health centers, 31 health posts, 66 health extension workers and 82 all category health workers. According to the projected population by the health office for $2018 / 19$, the total population was estimated to be 138,011 among which $50.9 \%$ (70248) were women and $3.22 \%(4,444)$ were mothers of children aged less than 12 months/surviving infants (office 2018/19).

\section{Study design}

A quantitative community based cross-sectional study design supplemented by qualitative study was used.

\section{Population}

\section{Source population}

Quantitative: All mothers of infants in Ambo district.

Qualitative: All husbands, mother-in-laws, \& traditional birth attendants for focus group discussions; and Abbaa-Gadaas/elders in Ambo district, health extension worker and maternal \& child health coordinator of Ambo district for key informant interview.

\section{Study population}

Quantitative: Selected mothers of infants living in the selected Gandas who fulfill the inclusion criteria.

Qualitative: Selected husbands of mothers of infants in the selected Gandas, mother-in-laws, and traditional birth attendants in Ambo district for focus group discussions; and Abba Gadaas/elders, health 
extension worker and maternal \& child health coordinator of the district for key informant interview.

\section{Inclusion and exclusion criteria}

\section{Inclusion criteria:}

a) All biological mothers who live in the ganda/kebele at least for the last six months \& had under oneyear old Child.

\section{Exclusion criteria}

Mothers who were acutely sick and unable to communicate during data collection.

\section{Sample size calculation}

The sample size (n) required for the study was calculated using the formula to estimate a single population proportion by considering the following assumptions. $Z a / 2=$ critical value for normal distribution at $95 \%$ confidence level which equals to $1.96(Z$ value at alpha $=0.05)$.

According to the study conducted in Debremarkos town of Amhara region in 2015, about $76.72 \%, 78.84 \%$ and $77.71 \%$ of mothers had good knowledge, favorable attitude and good practice of colostrum feeding respectively(27).

a) Hence, according to the study; $P=76.72 \%$ for knowledge:

$d(w)=$ margin of error of 0.05 with $95 \%$ confidence level.

$\mathbf{n}_{=}\left(\mathbf{Z}_{\mathrm{a} / 2}\right)^{2} * \mathrm{P}(1-\mathrm{P}) / \mathbf{d}^{2}=(1.96)^{2 *} .77(1-.77) / 0.05^{2}$

$n=272$ Mothers with below one years old children (including non-response rate of $10 \%$ )

$=272+(272 * 10 \%)=299$ Mothers of infants.

b) According to study conducted in Debremarkos town in Amhara region (2015),

$P=(78.84 \%)$ for attitude.

$d(w)=$ margin of error of 0.05 with $95 \%$ confidence level.

$\mathbf{n}_{=}\left(\mathbf{Z}_{\mathrm{a} / 2}\right)^{2} * \mathrm{P}(1-\mathrm{P}) / \mathbf{d}^{2}=(1.96)^{2 *} .79(1-.79) / 0.05^{2}=254$ (including $10 \%$ non-respondents)

$=282$ Mothers of infants.

C) According to study conducted in Debremarkos town in Amhara region (2015): 
$P=(77.71 \%)$ for practice.

$d(w)=$ margin of error of 0.05 with $95 \%$ confidence level.

$n=\left(Z_{a / 2}\right)^{2} * P(1-P) / d^{2}$

$=(1.96)^{2 *} .78(1-.78) / 0.05^{2}$

$=264$ (including 10\% non-respondents)

$=291$ Mothers of infants.

Here, from the study conducted in Debremarkos town of Amhara region, the result for knowledge of the respondents bequeathed representative sample size for this study. Since the sampling procedure during this study was affected by design effect, the sample size becomes, $(299 * 1.5=449)$.

Concerning focus group discussion, till saturation of ideas, two FGDs were conducted. The first was conducted in A/Qora ganda at Awaro HP and the second was conducted at Meti HC including mother in laws, mothers of infants, husbands of a mothers of infants, \& traditional birth attendants. Three participants for key informant interview were purposively selected and interviewed. The participants were the district $\mathrm{MNCH}$-coordinator, $\mathrm{HEW}$, and one religious leader in Ambo district.

\section{Sampling procedure}

Ambo district administration has 33 Gandas (the smallest administrative unit in Oromiya). Thirty percent (11) Gandas were selected as study Gandas by lottery method. These were: Y/Cebo, Bilo, G/Qora, G/wadessa, Golja, U/Qorke, Mexi, N/Warqa, Amaro, Tule, and Wadessa. Study population were assigned proportionally to the selected gandas/sub districts. From family folder/there is a list of mothers of infants. The list/sampling frame was already there, because these were targeted for immunization. Then, to select the study population, all source population of respective gandas were coded. Mothers of infants were selected by simple random sampling, lottery method. Since the households' zone/Gare were clearly indicated on the cover of the family folder, the selected mothers were easily traced and interviewed. Where it was difficult, local guiders were hired in two kebeles for some days to reach those selected households with mothers of infants.

\section{Study variables}

Dependent variables:

- Knowledge towards colostrum.

- Attitude towards colostrum. 
- Practice of colostrum feeding within an hour to 2-3 days.

Independent variables:

- Socio-demographic characteristic of the mother

$\circ$ Age

- Sex of neonate

- Marital status,

- Educational status

- Occupation of mother

- Area of residence

- Housing ownership

- Possession of cow milk at birth

- Average monthly income

- Providers/health service-related variables

- Whether the birth/pregnancy of current neonate wanted

- Attendance of ANC

- Number of ANC visit

- Reception/treatment by health service providers

- Maternal counseling by ANC provider on benefit of colostrum

- Information regarding colostrum

- Attendance of pregnant mothers' forum

- Place of delivery

- Attendance of PNC

- Obstetric and medical variables of the baby

- Mode of delivery

- Health status of the newborn at birth

- Health status of the mother during pregnancy/at birth.

\section{Operational Definition}

Knowledge: In this study refers to awareness of mother of infant (s) about colostrum breast milk. It was evaluated by the mother's answer to the questions (11).

Good knowledge: Those mothers who answer $\geq 60 \%$ questions of knowledge related questions (11).

Poor knowledge: Those mothers who answer $<60 \%$ questions of knowledge related questions (11). 
Attitude: The way that mothers of infants think towards colostrum feeding to their infants.

Positive attitude: Those mothers who answer $\geq 60 \%$ of attitude related questions.

Negative attitude: Those mothers who answer $<60 \%$ of attitude related questions.

Practice: The behavior of mothers of infants on colostrum feeding to their current infants within one hour to two-three days $(9,21,31-33)$.

\section{Data collection instrument and methods}

Structured questionnaire for face to face administration and semi structured guiding questionnaire for quantitative \& qualitative data collection were adapted and modified from previous similar studies respectively $(9,21,31-33)$. For qualitative, in addition to semi-structured questionnaire, smartphone was used. One teacher from each selected Gandas as data collector and 11 supervisors who have BSc from respective PHCU were provided one day training/orientation. Qualitative data were also collected through FGD, and key informant interview. After the data collection for qualitative, the data were transcribed in to English to answer the semi-structured questions. The investigator and two supervisors facilitated the sessions of FGD but the investigator alone conducted the three in-depth interviews.

\section{Data quality control}

The tools for quantitative data collection were prepared in English language and translated in to Afaan Oromo and then re-translated back to English by language expert/professional for its consistency. Data collectors and supervisors were trained for one day on how to interview and record. Pre-test was done in A/Qora at $5 \%(5 \% * 449=20)$ of actual respondents. After the pre- test, no unclear questions were founded to amend. But the data from the pre-test was not included in the analysis of actual study. Regularly, monitoring and supervision of the overall activity was conducted by the supervisors \& investigator. To maintain the quality of data while entering data, Epidata version 3.1 was used.

\section{Data processing and analysis}

After checking the completeness and consistency of the quantitative data on the printed form of the questionnaire; it was cleaned, coded and entered into Epidata version 3.1. The data analysis was performed by using SPSS version 21.0 statistical package for analysis. Descriptive statistics was used to show the knowledge, attitude and practices of the mothers on colostrum feeding in the district. Binary and multivariable logistic regression analyses were carried out to identify the factors associated with colostrum feeding. The variables with $p$-value $<0.2$ in binary logistic regression were included in multivariable regression analysis model. Variables at $p$-value $<0.05$ in the final multivariable model were concluded as factors associated with the practice of colostrum feeding. 
Qualitative data were transcribed into English text by the investigator. Thematic framework analysis approach was used to analyze the qualitative data. Finally, the result was presented in triangulation with the quantitative findings.

\section{Results}

\section{Socio demographic characteristics}

A total of 429 mothers of children aged less than 12 months were included in the study with response rate of $95.54 \%$. The mean ( \pm SD) age of mothers was 26.61 ( \pm 5.7$)$ years ranging from 16 to 41 . The majority of the mothers 125 (29.1\%) were between 26-30 years of age. Almost all, $393(91.61 \%)$ of the respondents were rural dwellers. About two-third of the study population, 255 (59.4\%) were Orthodox but $135(33.5 \%)$ were protestant religion followers. Almost all of the respondents $424(98.8 \%)$ were from Oromo ethnic group. About one fifth of mothers 78 (18.2\%) cannot read and write. Most of the mothers 397 (92.5\%) were in marital union. Regarding average monthly income of the house-hold of study participants, 306(71.3\%) were earning less than 1000 birr, 108 (25.2\%) were earning 1000-3000 birr, 10 (2.3\%) were earning 3001-5000 birr, and $5(1.2 \%)$ earned more than 5000 birrs per month (Table 1 ). 
Table 1

Socio-demographic characteristics of mothers of infants in Ambo district of west Shoa zone, Oromia region, Ethiopia, 2019

\begin{tabular}{|c|c|c|c|}
\hline & Category & Frequency & Percent \\
\hline \multirow[t]{5}{*}{ Age of the mother in years $(n=429)$} & $15-20$ & 75 & 17.5 \\
\hline & $21-25$ & 116 & 27 \\
\hline & $26-30$ & 125 & 29.1 \\
\hline & $31-35$ & 87 & 20.3 \\
\hline & $>36$ & 26 & 6.1 \\
\hline \multirow[t]{2}{*}{ Ethnicity $(n=429)$} & Oromo & 424 & 98.8 \\
\hline & Others* & 5 & 1.2 \\
\hline \multirow[t]{5}{*}{ Marital status $(n=429)$} & Single & 15 & 3.5 \\
\hline & married \& living together & 363 & 84.6 \\
\hline & Married but living apart & 34 & 7.9 \\
\hline & Divorce & 10 & 2.3 \\
\hline & Widowed & 7 & 1.6 \\
\hline \multirow[t]{5}{*}{ Education status of mother $(n=429)$} & can't read and write & 78 & 18.2 \\
\hline & read and write & 96 & 22.4 \\
\hline & Completed primary & 164 & 38.2 \\
\hline & Completed secondary & 44 & 10.3 \\
\hline & Preparatory \& above & 47 & 11 \\
\hline \multirow[t]{6}{*}{ Education status of husband $(n=397)$} & can't read and write & 39 & 9.8 \\
\hline & read and write & 63 & 15.9 \\
\hline & Primary complete & 154 & 38.8 \\
\hline & Secondary complete & 83 & 20.9 \\
\hline & Preparatory complete & 21 & 5.3 \\
\hline & college and above & 37 & 9.3 \\
\hline \multirow[t]{2}{*}{ Occupation status of husband $(n=397)$} & Farmer & 310 & 78.1 \\
\hline & Employed (GO/NGO) & 34 & 8.6 \\
\hline
\end{tabular}




\begin{tabular}{|c|c|c|c|}
\hline & Category & Frequency & Percent \\
\hline & Merchant & 40 & 10.1 \\
\hline & Others ${ }^{\star \star}$ & 13 & 3.3 \\
\hline \multirow[t]{4}{*}{ Occupation of the mother $(n=429)$} & house wife & 247 & 57.6 \\
\hline & Governmental employee & 22 & 5.2 \\
\hline & Merchant & 34 & 7.9 \\
\hline & Farmer & 126 & 29.3 \\
\hline \multirow[t]{2}{*}{ Area of residence $(n=429)$} & Urban & 36 & 8.4 \\
\hline & Rural & 393 & 91.6 \\
\hline \multirow[t]{3}{*}{ Ownership of the house $(n=429)$} & Owned & 346 & 80.7 \\
\hline & Rented & 57 & 13.3 \\
\hline & Others $^{\star \star \star}$ & 26 & 6.1 \\
\hline
\end{tabular}

\section{Health service utilization and birth experience of mothers}

Among the mothers participated in the study, 97 (22.6\%) had only one child, 209 (48.8\%) had two to five children, and 123 (28.6\%) had more than five children. Among 315 (73.4\%) ANC attending mothers for the pregnancy of the current infant, about one third (34\%) visited four and more times, $63.1 \%$ visited two to three times \& the rest $2.9 \%$ visited only once. Only $126(40 \%)$ were counseled on the importance of colostrum feeding (Table 2).

In this study, about two third 256 (59.7\%) of the mothers gave birth at different health facilities of different types, but 173 (40.3\%) at home (Fig. 3). Regarding mode of delivery, majority of study participants, $383(89.3 \%)$ gave birth on spontaneous vaginal delivery, $27(6.3 \%)$ instrumentally (forceps/vacuum), and the rest 19 (4.4\%) by caesarian section (C/S) at hospitals. One fifth of study participants $89(20.7 \%)$, were attending PNC within 2-3 days. Three-fourth of the mothers $332(77.4 \%)$ had information on advantage of colostrum feeding from different sources: 176 (53\%) from health professionals/health facilities, $143(43.1 \%)$ from community and $13(3.9 \%)$ heard from mass-media (Table 2). 
Table 2

Health service utilization and mode of delivery among mothers of infants in Ambo district of west Shoa zone, Oromia, Ethiopia, 2019

\begin{tabular}{|llll|}
\hline Variables & Alternatives & Frequency & Percent \\
\hline $\begin{array}{l}\text { ANC follow up for the pregnancy of youngest child } \\
(n=429)\end{array}$ & Yes & 315 & 73.4 \\
\cline { 2 - 4 } & No & 114 & 26.6 \\
\hline $\begin{array}{l}\text { Those counselled on the importance of colostrum } \\
\text { during ANC }(n=315)\end{array}$ & Yes & 126 & 29.4 \\
\cline { 2 - 4 } & No & 189 & 44.1 \\
\hline Mode of delivery $(n=429)$ & SVD & 383 & 89.3 \\
\cline { 2 - 4 } & Instrumental/forceps & 27 & 6.3 \\
\hline $\begin{array}{l}\text { Did you attend PNC follow up within the first 3-4 } \\
\text { days }(n=429)\end{array}$ & C/S & 19 & 4.4 \\
\cline { 2 - 4 } & Yes & 89 & 20.7 \\
\cline { 2 - 4 }
\end{tabular}

\section{Knowledge of respondents about colostrum feeding}

To assess the knowledge of the mothers on colostrum feeding, according to the predetermined criteria, 278 (64.8\%) mothers had good knowledge (Fig. 4). Of the participants of the study, 335 (78.1\%) responded that colostrum is yellowish, thick and sticky in consistency. While about two third 257 (59.9\%) knew that colostrum is the first vaccine that prevents diseases and best to be given to baby within an hour, slightly more than half of the respondents 242 (56.4\%) responded that colostrum is rich in protein which helps the baby grow well (Table 3). 
Table 3

Knowledge of colostrum breast milk among mothers of infants in Ambo district of west Shoa zone, Oromiya, Ethiopia, 2019

\begin{tabular}{|lll|}
\hline Descriptions & Yes & No \\
\hline Colostrum is yellowish in color, thick, and sticky in consistency & $335(78.1 \%)$ & $94(21.9 \%)$ \\
\hline Colostrum is first vaccine given to the baby & $257(59.9 \%)$ & $172(40.1 \%)$ \\
\hline Colostrum is high in protein \& help the baby to grow. & $242(56.4 \%)$ & $187(43.6 \%)$ \\
\hline $\begin{array}{l}\text { The mother knows early initiation of BF with colostrum feeding } \\
\text { strengthen baby-mother bondage. }\end{array}$ & $394(91.8 \%)$ & $35(8.2 \%)$ \\
\hline $\begin{array}{l}\text { The mother is aware of the initiation of colostrum feeding within an } \\
\text { hour and continue to three days after birth. }\end{array}$ & $327(76.2 \%)$ & $102(23.8 \%)$ \\
\hline $\begin{array}{l}\text { Even if the mother/baby got sick, colostrum feeding within one hour to } \\
\text { three days after delivery should be started }\end{array}$ & $188(43.8 \%)$ & $241(56.2 \%)$ \\
\hline $\begin{array}{l}\text { Early initiation of BF with colostrum prevents breast pain/engorgement } \\
\text { after birth. }\end{array}$ & $327(76.2 \%)$ & $102(23.8 \%)$ \\
\hline $\begin{array}{l}\text { The mother aware of that early initiation of colostrum feeding within } \\
\text { one hour prevents vaginal bleeding (PPH) after birth. }\end{array}$ & $51(11.9 \%)$ & $378(88.1 \%)$ \\
\hline $\begin{array}{l}\text { Mothers aware of to start breastfeeding with colostrum often on } \\
\text { demand day and night without provision of any pre-lacteals. }\end{array}$ & $287(66.9 \%)$ & $142(33.1 \%)$ \\
\hline
\end{tabular}

\section{Attitude of study participants towards colostrum breast milk}

According to the response of study participants to questions to assess attitude, only $250(58 \%)$ had favorable attitude towards colostrum breast milk. Ninety nine mothers $(23 \%)$ believed that they had no colostrum, 135(31.4\%) perceived colostrum breast milk as dirty and looks like pus, 151 (35.2\%) believed that colostrum causes intestinal obstruction, 227(52.9\%) baby didn't like \& cannot suck colostrum, $210(44.3 \%)$ colostrum makes the baby sick \& difficult to digest, and $195(45.4 \%)$ needs to be discarded (Table 4). 
Table 4

Attitude towards colostrum breast milk among mothers of infants in Ambo district of west Shoa zone, Oromia region, Ethiopia, 2019

\begin{tabular}{|lllll|}
\hline Variable Category & $\begin{array}{c}\text { Strongly agree } \\
\mathbf{N}(\%)\end{array}$ & $\begin{array}{l}\text { Agree } \\
\mathbf{N}(\%)\end{array}$ & $\begin{array}{l}\text { Disagree } \\
\mathbf{N}(\%)\end{array}$ & $\begin{array}{l}\text { Strongly dis- } \\
\text { agree N (\%) }\end{array}$ \\
\hline Believed that she has no colostrum. & $13(3 \%)$ & $86(20 \%)$ & $\begin{array}{l}248 \\
(57.8 \%)\end{array}$ & $82(19.8 \%)$ \\
\hline It is dirty, looks like pus. & $19(4.4 \%)$ & $116(27 \%)$ & $\begin{array}{l}199 \\
(46.4 \%)\end{array}$ & $95(22.1 \%)$ \\
\hline Causes obstruction in the intestines & $21(4.9 \%)$ & $\begin{array}{l}130 \\
(30.3 \%)\end{array}$ & $\begin{array}{l}202 \\
(47.1 \%)\end{array}$ & $76(17.7 \%)$ \\
\hline $\begin{array}{l}\text { Colostrum breast milk Causes } \\
\text { diarrhea }\end{array}$ & $22(5.1 \%)$ & 139 & $201(46.9 \%)$ & $67(15.6 \%)$ \\
\hline $\begin{array}{l}\text { Baby did not like colostrum breast } \\
\text { milk }\end{array}$ & $54(12.6 \%)$ & $173(40.3 \%)$ & $\begin{array}{l}118 \\
(27.5 \%)\end{array}$ & $84(19.6 \%)$ \\
\hline $\begin{array}{l}\text { Colostrum makes the baby sick } \\
\text { Baby can't suck colostrum }\end{array}$ & $44(10.3 \%)$ & $146(34 \%)$ & 155 & $84(19.6 \%)$ \\
\hline $\begin{array}{l}\text { It is difficult to digest and needs to } \\
\text { be discarded }\end{array}$ & $28(6.5 \%)$ & $\begin{array}{l}167 \%) \\
(38.9 \%)\end{array}$ & $150(35 \%)$ & $84(19.6 \%)$ \\
\hline $\begin{array}{l}\text { My family says it should not to be } \\
\text { given }\end{array}$ & $145(33.8 \%)$ & $108(25.2$ & $88(20.5 \%)$ & $88(20.5 \%)$ \\
\hline
\end{tabular}

\section{Practice of respondents towards colostrum feeding}

Among breast feeding (402 (93.7\%) mothers, 227 (56.5\%) gave colostrum to their baby within one hour to three days. Seventy three percent (73.1\%) of colostrum fed mothers were feeding within an hour but the rest $61(26.9 \%)$ fed after one hour to one day. According to the response of the mothers for not feeding colostrum within an hour, 54 (88.5\%) delayed till they took bath, 2(3.3\%) forbidden culturally and $5(8.2 \%)$ due to illness either to the babies or mothers/both.

Among those mothers who didn't ever feed colostrum to their neonate (43.5\%), 75 (42.9\%) reasoned out that mother-in-law forbidden, 77 (44\%) explained that colostrum causes illness even death, and the rest 23 (13.1\%) couldn't justify why they avoided colostrum. Fourteen (14) of the mothers fed the first 2-3 days with other foods (pre-lacteal) till colostrum goes, but the majority 161 (92\%) expressed and discarded the colostrum before each feed till it goes (Table 5). 
Table 5

Colostrum feeding practices among mothers of infants in Ambo districts of west Shoa zone, Oromia, Ethiopia, 2019.

\begin{tabular}{|c|c|c|c|}
\hline Category & & Frequency & Percent \\
\hline \multirow[t]{2}{*}{ Maternal breast feeding practice; $(n=429)$} & Yes & 402 & 93.7 \\
\hline & No & 27 & 6.3 \\
\hline \multirow{3}{*}{$\begin{array}{l}\text { The reason for not mothers not feed breast } \\
\text { milk }(n=27)\end{array}$} & III health & 6 & 22.2 \\
\hline & I don't have BM & 19 & 70.4 \\
\hline & $\begin{array}{l}\text { Other, (stay beautiful/in } \\
\text { good posture) }\end{array}$ & 2 & 7.4 \\
\hline \multirow{2}{*}{$\begin{array}{l}\text { Breast feeding mothers who were colostrum } \\
\text { feeding: }(n=402)\end{array}$} & Yes & 227 & 56.5 \\
\hline & No & 175 & 43.5 \\
\hline \multirow{2}{*}{$\begin{array}{l}\text { The time mothers started colostrum breast } \\
\text { feeding }(n=227)\end{array}$} & Within an hour & 166 & 73.1 \\
\hline & After an hour but in a day & 61 & 26.9 \\
\hline \multirow{3}{*}{$\begin{array}{l}\text { The reason mothers feed colostrum after an } \\
\text { hour: }(n=61)\end{array}$} & Till take bath & 54 & 88.5 \\
\hline & III health & 5 & 8.2 \\
\hline & It is cultural & 2 & 3.3 \\
\hline \multirow[t]{3}{*}{$\begin{array}{l}\text { The reason mothers not feeding colostrum } \\
\text { completely: }(n=175)\end{array}$} & $\begin{array}{l}\text { Mother in-law prohibits \& it is } \\
\text { not cultural }\end{array}$ & 75 & 42.9 \\
\hline & Causes illness/death to baby & 77 & 44 \\
\hline & I don't know the reason & 23 & 13.1 \\
\hline \multirow[t]{2}{*}{$\begin{array}{l}\text { The practice of the mother who didn't feed } \\
\text { colostrum; }(n=175)\end{array}$} & $\begin{array}{l}\text { The first } 2-3 \text { days other } \\
\text { feeds, then BF }\end{array}$ & 14 & 8 \\
\hline & $\begin{array}{l}\text { Discard the colostrum then } \\
\text { feed }\end{array}$ & 161 & 92 \\
\hline
\end{tabular}

Regarding the qualitative data collected, two sessions of focus group discussions were conducted. Supporting the practices of colostrum feeding to baby within one hour to three days, about two thirds of both focus group discussants, stated that "colostrum is the first vaccine that prevents diseases, first food to build the baby and helps to grow, prevents hunger, and so that, any pre-lacteals should be avoided and colostrum should be the first teste of the neonate". In contrast to this, $47 \& 53$-year-old mothers said that "in their community, colostrum is believed to cause abdominal cramp, hence to prevent such problem as grandmother of children both said that 'we recommend to express the colostrum first then feed breast milk for the first two to three days'. Another woman who was 39 years old said that, 'since colostrum 
causes abdominal cramp and raw butter cleans the stomach of infants, I recommend mothers to discard colostrum and to feed with raw butter before breastfeeding initiation". One of untrained traditional birth attendant also supported the idea of expressing \& discarding colostrum in the first 2-3 days before each feed.

The district MNCH coordinator and one HEW on separate interview said that lack of indicators for breast/colostrum feeding in DHIS ${ }_{2}$ in supervisory checklist was the problem affected colostrum feeding. This causes health providers not to give counselling service on the advantage of colostrum feeding at every contact point; And even they fail to help the mothers who gave birth at health facilities during the stay at health institutions for immediate post-natal care on colostrum feeding'. Additionally, both respondents responded that 'there is also low commitment of service providers on transmission of health information on the importance of colostrum feeding \& even some materials like flip charts were not clear for easy use and outdated. As a result, lack of awareness of the community as a whole, especially the most influential segment, is also the underline cause of colostrum feeding malpractice. Hence, as actions to be taken they proposed that ' $D H I S_{2}$ \& supervisory checklist has to be revised, IEC/BCC need to be updated \& made easy to use at all levels especially at community level by central and regional governments'.

\section{Factors associated with colostrum feeding among the study participants}

In binary logistic regression analysis; maternal age $21-25$, completing preparatory \& above schools, being house wife in occupation, being owner of the house, wanted/planned birth to the young infant, stable maternal health during pregnancy/birth, attending ANC, counselling on importance of colostrum feeding, ANC attendance for two \& above sessions, participating on pregnant mother forum, giving birth at HFs, good neonatal health at/soon after birth, visit for PNC within the first two to three days, \& mothers who got information on advantages of colostrum were found positively associated with colostrum feeding practice (Table 6).

In multivariable logistic regression analysis, good health status of the neonate at or soon after birth, and maternal PNC visit within the first two to three days were positively associated with colostrum feeding practice. But unplanned/unwanted pregnancy/birth to the infant, mothers who were suffering from any health problem during pregnancy/at birth, lack of counseling on the importance colostrum feeding, giving birth at home, lack of information on the importance of colostrum feeding were negatively associated factors with colostrum feeding practices. Mothers who gave birth to healthier babies were 15 times (AOR 14.87, 95\% Cl: 5.00-44.27) more likely to feed colostrum than mothers who had babies with any health problem. The mothers who were attending PNC within the first two to three postpartum days were 3 times (AOR 3.48, 95\% Cl: 1.23-9.85) more likely to feed colostrum than mothers who didn't attend PNC services. 
Among the study participants, mothers whose pregnancy/birth was unwanted were $75.7 \%$ (AOR 0.243, $95 \% \mathrm{Cl}: 0.113-0.527)$ less likely to feed colostrum compared to mothers whose pregnancy/birth is wanted. Mothers who were having any complain/health problem during birth/pregnancy were $62 \%$ (AOR $0.380,95 \% \mathrm{Cl}: 0.161-0.903)$ less likely to practice colostrum feeding for their neonate compared to mothers who were healthy during pregnancy/giving birth. Mothers who were attending ANC service but not counselled on the importance of colostrum feeding were $73.6 \%$ (AOR $0.264,95 \% \mathrm{Cl}$ : $0.103-0.675$ ) less likely to feed colostrum than mothers who were counselled. The mothers who gave birth at home were $76.1 \%$ (AOR $0.239,95 \% \mathrm{Cl}: 0.111-0.516$ ) less likely to practice colostrum feeding than those mothers who gave birth at health institutions. Mothers who didn't get information on the advantage of colostrum feeding were $96 \%$ (AOR $0.040,95 \% \mathrm{Cl}$ : .013-.125) less likely to feed colostrum for their neonates with colostrum than mothers who had information on the importance of colostrum feeding (Table 6). 
Table 6

Binary and multivariable logistic regression analysis showing associated factors towards colostrum feeding practices among mothers of infants in Ambo district of west Shoa zone, Oromiya region, Ethiopia, 2019

\begin{tabular}{|lllll}
$\begin{array}{l}\text { Explanatory } \\
\text { variables }\end{array}$ & \multicolumn{2}{l}{ Have you fed colostrum? } & Binary regression & \multicolumn{2}{l}{ Multi-variate } \\
\cline { 2 - 5 } & No $=0$ & Yes $=1$ & COR 95\% Cl & $\begin{array}{l}\text { P- } \\
\text { Value }\end{array}$
\end{tabular}$\quad$ AOR 95\% Cl

\section{Maternal age}

$\begin{array}{lccl}\begin{array}{l}\text { 1. } 15-20 \text { years } \\ \text { age }\end{array} & 28(47.5 \%) & 31(52.5 \%) & 0.709(.277,1.818) \\ \begin{array}{l}\text { 2. } 21-25 \text { years } \\ \text { age }\end{array} & 36(31.9 \%) & 77(68.1 \%) & 0.367(.152, .889) \\ \begin{array}{l}\text { 3. } 26-30 \text { years } \\ \text { age }\end{array} & 49(40.2 \%) & 73(59.8 \%) & 0.527(.221,1.257) \\ \begin{array}{l}\text { 4. } 31-35 \text { years } \\ \text { age }\end{array} & 48(57.8 \%) & 35(42 \%) & 1.077(.437,2.655) \\ \begin{array}{l}\text { 5. }>36 \text { years age } \\ \text { 14(56\%) }\end{array} & 11(44 \%) & 1: 00\end{array}$

\section{Sex of neonate}

$\begin{array}{llllll}\text { 1. Male } & 78(39.2 \%) & 121(60.8 \%) & 0.704(.474,1.047) & 0.792 & 1.094(.559,2.142) \\ \text { 2. Female } & 97(47.8 \%) & 106(52.2 \%) & \mathbf{1}: 00 & & \end{array}$

\section{Marital Status}

$\begin{array}{llll}\begin{array}{l}\text { 1. Mothers in } \\ \text { Marital union (with } \\ \text { husband) }\end{array} & 159(42.1 \%) & 219(57.9 \%) & 0.673(0.378, .780) \\ \begin{array}{l}\text { 2. Mothers with no } \\ \text { husband }\end{array} & 16(66.7 \%) & 8(33.3 \%) & \mathbf{1 : 0 0}\end{array}$

\section{Educational status of the mother}

\begin{tabular}{lccl}
$\begin{array}{l}\text { 1. Can't read \& } \\
\text { write }\end{array}$ & $36(50 \%)$ & $36(50 \%)$ & $1: 00$ \\
\hline 2. Read \& write & $41(43.6 \%)$ & $53(56.4 \%)$ & $\begin{array}{l}0.7735(.418, \\
1.432)\end{array}$ \\
$\begin{array}{l}\text { 3. Completed } \\
\text { primary }\end{array}$ & $74(47.7 \%)$ & $81(52.3 \%)$ & $0.9135(.522,1.598)$ \\
$\begin{array}{l}\text { 4. Completed } \\
\text { secondary }\end{array}$ & $13(34.2 \%)$ & $25(65.8 \%)$ & $0.5199(.230,1.174)$ \\
$\begin{array}{l}\text { 5. Preparatory } \\
\text { completed }\end{array}$ & $5(27.7 \%)$ & $17(82.3 \%)$ & $\begin{array}{l}0.2941(0.098- \\
0.883)\end{array}$ \\
\hline
\end{tabular}




\begin{tabular}{|c|c|c|c|c|c|}
\hline \multirow{2}{*}{$\begin{array}{l}\text { Explanatory } \\
\text { variables }\end{array}$} & \multicolumn{2}{|c|}{ Have you fed colostrum? } & \multirow{2}{*}{$\begin{array}{l}\text { Binary regression } \\
\text { COR 95\% Cl }\end{array}$} & \multicolumn{2}{|c|}{ Multi-variate } \\
\hline & No $=0$ & Yes $=1$ & & $\begin{array}{l}\mathrm{P}- \\
\text { Value }\end{array}$ & AOR 95\% Cl \\
\hline 6. College \& above & $6(28.6 \%)$ & $15(71.4 \%)$ & $\begin{array}{l}0.4000(.139- \\
1.147)\end{array}$ & & \\
\hline \multicolumn{6}{|c|}{ Occupational status of the mother } \\
\hline 1. House wife & $117(48 \%)$ & $127(52 \%)$ & $\begin{array}{l}1.727(1.080- \\
2.763)\end{array}$ & & \\
\hline 2. Employed & $10(37 \%)$ & $18(63 \%)$ & $0.778(.276-2.191)$ & & \\
\hline 3. Merchant & $18(41.9 \%)$ & $25(58.1 \%)$ & $\begin{array}{l}1.180(0.529- \\
2.634)\end{array}$ & & \\
\hline 4. Farmer & $41(36.3 \%)$ & $72(63.7 \%)$ & 1:00 & & \\
\hline \multicolumn{6}{|l|}{ Area of residence } \\
\hline 1. Urban & $21(49 \%)$ & $22(51 \%)$ & $\begin{array}{l}1.329(0.658- \\
2.685)\end{array}$ & & \\
\hline 2. Rural & $176(45.6 \%)$ & $210(54.4 \%)$ & 1:00 & & \\
\hline \multicolumn{6}{|l|}{ Housing ownership } \\
\hline 1. Owned & $139(40.8 \%)$ & $202(59.2 \%)$ & $\begin{array}{l}0.290(0.109- \\
0.774)\end{array}$ & 0.286 & $\begin{array}{l}0.449(0.103- \\
1.956)\end{array}$ \\
\hline 2. Rented & $32(52.5 \%)$ & $29(47.5 \%)$ & $\begin{array}{l}0.503(0.166- \\
1.521)\end{array}$ & 0.69 & $\begin{array}{l}1.401(0.267- \\
7.367)\end{array}$ \\
\hline 3. Other & $14(51.9 \%)$ & $13(48.1 \%)$ & 1:00 & & \\
\hline \multicolumn{6}{|c|}{ Access to cow milk at birth } \\
\hline 1. Yes & $78(47.5 \%)$ & $86(52.5 \%)$ & 1:00 & & \\
\hline 2. No & $97(41.3 \%)$ & $141(58.7 \%)$ & $\begin{array}{l}1.3189(0.883- \\
1.969)\end{array}$ & 0.895 & $\begin{array}{l}1.052(0.490- \\
2.260)\end{array}$ \\
\hline \multicolumn{6}{|c|}{ Average monthly income } \\
\hline 1. $<1000$ & $126(43.4 \%)$ & $164(56.6 \%)$ & 1:00 & & \\
\hline 2. $1000-3000$ & $54(47.8 \%)$ & $59(52.2 \%)$ & $\begin{array}{l}3.031(0.335- \\
27.462)\end{array}$ & & \\
\hline 3. $3001-5000$ & $5(31.3 \%)$ & 11(68.7\%) & $\begin{array}{l}3.703(0.4000- \\
34.266)\end{array}$ & & \\
\hline 4. $>5000$ & $3(30 \%)$ & $7(70 \%)$ & $\begin{array}{l}1.00(0.068- \\
14.640)\end{array}$ & & \\
\hline
\end{tabular}


Explanatory variables
Have you fed colostrum? Binary regression Multi-variate

$\begin{array}{llll}\text { No }=0 & \text { Yes }=1 & \text { COR } 95 \% \mathrm{Cl} & \begin{array}{l}\text { P- } \\ \text { Value }\end{array}\end{array}$

Is the birth (pregnancy) to this infant wanted?

$\begin{array}{llllll}\text { 1. Yes } & 109(36 \%) & 190(64 \%) & 1: 00 & & \\ \text { 2. No } & 66(64 \%) & 37(36 \%) & .322(0.202-0.513) & 0 & 0.243(0.11- \\ & & & & 0.527)^{\star}\end{array}$

Presence of health problem to the mother
1. Yes
$41(56 \%)$
$32(44 \%)$
$1.86(1.17-3.11)$
0.028
$0.380(.161-$
$0.903)^{*}$
2. No
$134(44 \%) \quad 227(56 \%) \quad 1: 00$

\section{ANC follow up status}

$\begin{array}{llllll}\text { 1. Yes } & 117(37.6 \%) & 194(62.4 \%) & \mathbf{1 : 0 0} & & \\ \text { 2. No } & 58(63.7 \%) & 33(36.3 \%) & 0.34(0.211-0.557) & 0.495 & \begin{array}{l}0.513(.076- \\ 3.485)\end{array}\end{array}$

\section{Sessions ANC attended}

$\begin{array}{llllll}\text { 1. Once } & 6(66.7 \%) & 3(33.3 \%) & 1: 00 & & \\ \text { 2. two-three } & 87(44.6 \%) & 108(55.4 \%) & \begin{array}{l}6.916(1.609- \\ 29.737)\end{array} & 0.367 & \begin{array}{l}0.392(0.052- \\ 2.988)\end{array} \\ & & & \begin{array}{l}2.785(1.632- \\ 4.756)\end{array} & 0.297 & \begin{array}{l}0.253(0.019- \\ 3.349)\end{array}\end{array}$

\section{Attended on pregnant mothers' forum}
1. Yes
$13(12.4 \%) \quad 92(87.6 \%)$
$0.138(0.073-$
$0.263)$
$\begin{array}{ll}0.365 & 0.619(0.220- \\ & 1.745)\end{array}$

2. No 104(50.5\%) 102(49.5\%) $\quad \mathbf{1 : 0 0}$

\section{Colostrum feeding counseling during ANC}

$\begin{array}{llllll}\text { 1. Yes } & 18(14 \%) & 108(86 \%) & 1: 00 & & \\ \text { 2. No } & 99(53 \%) & 86(47 \%) & .145(0.081-0.258) & 0.006 & 0.264(0.103- \\ & & & & & 0.675)^{\star}\end{array}$

Site of birth for youngest neonate

$\begin{array}{llllll}\text { 1. Health Facilities } & 77(31 \%) & 170(69 \%) & 1: 00 & & \\ \text { 2. Home } & 98(63 \%) & 57(37 \%) & .263(0.173-0.402) & 0 & 0.239(0.111- \\ & & & & & 0.516)^{\star}\end{array}$




\begin{tabular}{|c|c|c|c|c|c|}
\hline \multirow{2}{*}{$\begin{array}{l}\text { Explanatory } \\
\text { variables }\end{array}$} & \multicolumn{2}{|c|}{ Have you fed colostrum? } & \multirow{2}{*}{$\begin{array}{l}\text { Binary regression } \\
\text { COR 95\% Cl }\end{array}$} & \multicolumn{2}{|c|}{ Multi-variate } \\
\hline & No $=0$ & Yes $=1$ & & $\begin{array}{l}\mathrm{P} \text { - } \\
\text { Value }\end{array}$ & AOR $95 \% \mathrm{Cl}$ \\
\hline \multicolumn{6}{|c|}{ Health problem to neonate at birth } \\
\hline 3. Yes & $33(67 \%)$ & $16(33 \%)$ & 1:00 & & \\
\hline 4. No & $142(40 \%)$ & $211(60 \%)$ & $3.06(1.62-5.00)$ & 0 & $\begin{array}{l}14.87(5.00- \\
\left.44.27^{*}\right)\end{array}$ \\
\hline \multicolumn{6}{|l|}{ Mode of delivery } \\
\hline 1. $S V D$ & $170(46.3 \%)$ & 197(53.7\%) & $\begin{array}{l}2.99(0.966- \\
0.9 .267)\end{array}$ & 0.474 & $\begin{array}{l}2.098(0.276- \\
15.946)\end{array}$ \\
\hline 2. Instrumental & $11(30.6 \%)$ & $25(69.4 \%)$ & $\begin{array}{l}1.049(0.249- \\
4.422)\end{array}$ & 0.441 & $\begin{array}{l}2.475(0.247- \\
24.833)\end{array}$ \\
\hline 3. $C / S$ & $8(30.8 \%)$ & $18(69.2 \%)$ & 1:00 & & \\
\hline \multicolumn{6}{|c|}{ Attendance of PNC within 2-3 days } \\
\hline 1. Yes & $22(26 \%)$ & $64(74 \%)$ & $\begin{array}{l}2.366(1.215- \\
4.624)\end{array}$ & 0.018 & $3.48(1.23-9.85)^{\star}$ \\
\hline 2. No & $153(48 \%)$ & $163(52 \%)$ & 1:00 & & \\
\hline \multicolumn{6}{|c|}{ Information about colostrum } \\
\hline 1. Yes & $112(34 \%)$ & $216(66 \%)$ & 1:00 & & \\
\hline 2. No & $63(85 \%)$ & $11(15 \%)$ & $11.045(5.59-21.8)$ & 0 & $\begin{array}{l}0.040(0.013- \\
0.125)^{\star}\end{array}$ \\
\hline
\end{tabular}

\section{Discussions}

The aim of this study was to assess Knowledge, Attitude, Practices and associated factors towards colostrum feeding among mothers of infants in ambo district of west Shoa zone, Oromia, Ethiopia 2019. About two-third of the mothers $(64.8 \%)$ have good knowledge of colostrum breast milk. In line with the studies conducted in India(34) (85.2\%), in Mekelle town (11) (89.7\%), and in D/Markos town(21) (76.72\%), the knowledge of the participants of current study was low. The significant difference might be due to cultural \& sociodemographic differences of the study participants; the studies were facility based/town in case of Mekelle and D/Markos and additionally small sample size (195) was allowed to participate for the study conducted in Mekelle. But it looks slightly higher than the study conducted in Raya Kobo district of Amhara region (9) (58\%) due to the difference of the study participants. In Raya Kobo, less than 24 months old children mothers were study participants where the response of mothers mostly might affected with recall biases. Cultural differences might also be the other reason for the differences. 
Regarding attitude of the mothers towards colostrum, $58 \%$ of current study participants have favorable attitude towards colostrum breast milk. In contrary to the current study, the study conducted in Mizan Tepi teaching hospital in 2017 of SNNPR, 69.4\% mother had favorable attitude towards colostrum(33). This difference might be due to, the study conducted in SNNPR was hospital based, studied among small sample size participants (207) while the current study was rural community based. Cultural \& sociodemographic difference of the communities might also be another reason for the variation.

Though breast feeding practice is optimum (93.7\%) in Ambo district, only $56.5 \%$ study participants fed their babies with colostrum. Compared to global, this was by far lower than the studies conducted in India $76.0 \%$ (8) and Kuwait $81.8 \%$ (35). Here, the huge difference might be due to the study area, cultural and sociodemographic differences. In addition, study conducted in Kuwait employed prospective cohort study design.

The studies conducted in Mekelle town (11), Kombolcha town (36) and in Raya Kobo district (9) revealed that $(80.5 \%),(88.6 \%)$, and $(86.5 \%)$ of the mothers were feeding colostrum to their neonate respectively. In general the difference might be due to cultural and sociodemographic differences. Specifically, for the studies conducted in Mekelle \& Kombolcha, the studies were conducted in town and health facility based. Additionally, small number of participants (195) were used for the study conducted in Mekelle town.

In current study, the mothers reported that grandmothers/other relatives/neighbors and/or untrained traditional birth attendants (38.7\%) were the most influential to let to avoid colostrum. Moreover, FGDs and KII revealed that grandmothers and untrained traditional birth attendants thought colostrum causes abdominal cramp in infants. Therefore, they influence mothers to avoid colostrum. Similarly, grandmothers tend to have strong influence not to feed colostrum to their infants in Somalia (37) and Bangladesh(38).

Similar to the practices in current study, the national nutrition program colostrum feeding practice in Ethiopia (39) and study conducted in Mizan Tepi (25) showed colostrum feeding practices as $60.2 \%$ \& 60.88 \& respectively. This is consistent with the current study might be due to the similarity of study design.

The other study conducted to assess suboptimal breast feeding and associated factors in rural communities of Jimma Arjo district in western Oromiya showed that among mothers who ever breastfed, more than half of mothers (62.6\%) initiated breastfeeding within first hour of delivery(40). Almost the finding of this study was similar with current study finding. This might be due to similarity of study design, cultural and sociodemographic characteristics of study populations.

According to the current study mothers who gave birth to babies without any health problem \& mothers who were attending PNC within the first two to three postpartum days were positively associated with colostrum feeding practices. Similarly, this was consistent with the study conducted in northern Ethiopia (30) and Aksum town of Tigray region in (31). The similarity might be due to similar study design with the current study. 
But, colostrum feeding practice was negatively associated with mothers whose birth/pregnancy was unwanted, the presence of any type of maternal sickness during pregnancy/birth, lack of maternal counselling on importance of colostrum feeding, home delivery, and lack of information on importance of colostrum breast milk were negatively associated with the practices of colostrum feeding to the neonate within one hour to three days (Table 6). similarly the study conducted in Kombolcha town of Amhara region (41): mothers with sick neonate, mothers who didn't counselled on colostrum feeding were more likely to avoid colostrum. In contrary to the finding of current study: area of residence, employment status of the husband, participation on pregnant mothers' forum, believes that pre-lacteal food is good were associated factors with avoidance of colostrum breast milk.

In this study, mothers who didn't give birth at health institutions were $76.1 \%$ less likely to practice colostrum feeding compared to mothers who gave birth at health institutions. Similarly, in India, mothers who gave birth at home were more likely to discard colostrum compared with mothers who gave birth at health institutions(34). Grandmothers and traditional birth attendants usually attend the birth in homes.

Moreover, the findings from FGDs and KII of this study showed that grandmothers and traditional birth attendants thought colostrum causes abdominal cramps in infants. Lack of indicators for breast/colostrum feeding in $\mathrm{DHIS}_{2}$ data entry/in supervisory checklist was the other problem obtained from KII. According to the respondents of the interview, this hindered health providers from provision of counselling on the advantage of colostrum feeding at every possible contact. Giving birth at home may create a favorable environment for different socio-cultural malpractices/colostrum avoidance. Alternatively, mothers who gave birth in health institutions might be counselled by health professionals about the advantages of colostrum.

\subsection{Strengths and limitations}

The strength of this study was that it included both quantitative and qualitative methods. But, as limitation, the information obtained from mothers might be subjected to recall bias and also shares the limitation of the cross-sectional study design.

\section{Conclusion}

This study showed that only about half of the mothers fed colostrum to the neonate within an hour to three days. While mothers who gave birth to baby without any health problem and PNC attendants within the first two to three days were positively associated with practice of colostrum feeding, but unplanned/unwanted pregnancy/birth to the infant, presence of maternal health problem during pregnancy/soon after birth, lack of counseling on the importance colostrum feeding to the neonate, home birth to the youngest infant, and lack of information on the importance of colostrum feeding were the factors negatively affecting the practices colostrum feeding.

\section{Recommendation}


Depending up on the finding of the study, even if it is difficult to recommend national/regional institution with the findings of one district, I would like to recommend FMOH/Oromiya regional health bureau, ZHD, district health office, health facilities as well as providers with the following recommendations.

FMOH \& ORHB:

The policy makers can/need to initiate new strategies and programs that addresses community needs. Taking the associated factors towards colostrum feeding into account, community-oriented, targeted, and specific, interventions has be designed. So that, counseling on colostrum feeding is made routine health service by service providers, indicators of colostrum feeding has to be integrated in to $\mathrm{DHIS}_{2}$ and supervisory checklists of family health activities.

\section{Zonal health department, Ambo district administration health office and PHCU:}

Strengthen capacity building for experts \& service providers. The intervention has to be implemented at household, community, and health facility level targeting important segments of the communities. Strengthen facilitative supervision to every level by using integrated supervision checklist, and provision of feedback for improvement. Regular meeting on performance review and planning has to be strengthened at all levels.

\section{Service providers:}

- Provision of health information on benefit of colostrum feeding to communities such as mothers, adolescents, and other influential.

- So that pregnancy/delivery is wanted \& provide counseling on the importance of colostrum breast milk: strengthen family planning, antenatal care, skilled delivery, postnatal care within the first two to three days For wanted pregnancy/child birth and get counselling on the importance of colostrum breast milk.

\section{Abbreviations}

- ANC-_-_-Antenatal Care

- BF-___-Breast Feeding

- DHIS-_-_-District Health Information System

- EBF-_-_-Exclusive Breast Feeding

- EDHS--_-Ethiopian Demographic \& Health Survey

- HEW-_--Health Extension Worker

- KAP-_-Knowledge, Attitude and Practice

- MIYCN---Maternal Infant and Young Child Nutrition

- PHCU-_--Primary Health Care Unit 
- PNC-_-_-Post-Natal Care

- SPSS-_-_-Statistical Program for Social Sciences

- Unicef--- United Nations Children's Fund

- WHO-_-_World Health Organization

\section{Declarations}

\section{Ethical consideration}

Ethical approval and clearance to conduct this research was obtained from Research and Ethical Review Committee of College of Medicine and Health Sciences of Ambo University. Permission to conduct the study in selected/respective gandas was also inquired \& obtained from Ambo district health Office. After explaining the aim of the study, indicating that anything identifier of the participants never included in the questionnaire, they were informed about confidentiality of the information they provided. For both literate and illiterate mothers, informed verbal consent was obtained before conducting the interview.

\section{Consent for publication}

It is not applicable.

\section{Availability of data and materials}

The datasets that used in this study for analysis and other information are available currently in the hands of the corresponding author and principal investigator. Therefore, they can provide it if requested.

\section{Competing interests}

None of the authors have any competing interests.

\section{Funding}

This study done at Ambo University material support that received by hands of Dereje Minase. However, the funder had no role in overall activities in the study such as; in study design, data collection, and analysis. Finally, the funder had no role in the decision to publish, or preparation of the manuscript for publication.

\section{Authors' contributions}

DM is the principal investigator. DM, JD and ET conceived and designed the study. DM analyzed the data and interpreted the results. JD, ET and TT assisted the analysis and interpretation of data. JD and TT prepared and critically reviewed the manuscript. All authors have read and approved the manuscript.

\section{Acknowledgments}


I would like to thank Ambo University for its support during this study and Ambo district health office for its support for data collection. In addition, our heartfelt thanks also extended to study participants who shared their priceless time to give information. Besides, we would like to thank data collectors \& supervisors for their commitment for quality data collection. Lastly but not the least, we would like to thank my family for their innumerable contributions.

\section{References}

1. Godhia M, Patel N. Colostrum - Its Composition, Benefits As A Nutraceutical: A Review. Curr Res Nutr Food Sci J. 2013;1(1):37-47.

2. WHO. Maternal, infant and young child nutrition Comprehensive implementation plan on maternal, infant and young child nutrition: biennial report Report by the Director-General. 2018;3(January).

3. Navigation S, Route NS. Guiding Principles and Ten Steps to protect, promote and support breastfeeding. 2015;

4. L. ML. The Golden Milk for Infants' Health. Glob J Intellect Dev Disabil. 2017; 1(4): 555566. DOI: 10.19080/ GJIDD.2017.01.555566. 2017;1(4):1-2.

5. Kuzma J. Knowledge, attitude and practice related to infant feeding among women in rural Papua New Guinea: A descriptive, mixed method study. Int Breastfeed J. 2013;8(1):1-5.

6. Kerala N. Infant Feeding Practices in A Well Baby Clinic of A Tertiary Hospital in. 2016;04(06):10886-92.

7. Rogers NL, Abdi J, Moore D, Nd'langui S, Smith LJ, Carlson AJ, et al. Colostrum avoidance, prelacteal feeding and late breast-feeding initiation in rural Northern Ethiopia. Public Health Nutr. 2011;14(11):2029-36.

8. Raina S, Mengi V, Singh G. Determinants of Prelacteal Feeding Among Infants of RS Pura Block of Jammu and Kashmir, India. Vol. 1, Journal of family medicine and primary care. 2012. 27-29 p.

9. Legesse M, Demena M, Mesfin F, Haile D. Factors associated with colostrum avoidance among mothers of children aged less than 24 Months in Raya Kobo district, North-eastern Ethiopia: Community-based cross-sectional study. J Trop Pediatr. 2015;61(5):357-63.

10. Federal ministry of health FHD. National Strategy for Child Survival in Ethiopia. Magzine Artic. 2005; (June 2015).

11. Gebrehiwot H, Thampi A, Kassaw Y, Fita N. Knowledge, Attitude, and Practice towards colostrum feeding among moters od antenatal care attendant pregnant women in Mekelle city health facilities , Mekelle-2018, . 2018;08:24836-41.

12. Unicef. Improving child nutrition, the achilmproving child nutrition, the achevable imperative for global progress, April 2013. Vol. 18, NCSL legisbrief. 2013. 1-2 p.

13. Ministry F. Mcn-National-Strategy-for-Infant-and-Young-Child-Feeding-Ethiopia. 2004;(April).

14. Federal ministry of health FHD. National Strategy for Child Survival in Ethiopia. Magzine Artic. 2015; (June 2015). 
15. UNICEF. Infant and Young Child Feeding: Programming Guide. Nutr Sect UNICEF. 2012;(May):173.

16. Central Statistical Agency (CSA) [Ethiopia] and ICF. 2016. EDHS 2016. Addis Ababa, Ethiopia, and Rockville, Maryland, USA: CSA and ICF. 2017.

17. Goyal MK, Tomar A. Original article: Study of knowledge, attitude and practice towards feeding of colostrum in a tertiary care center of Jaipur, Rajasthan. 2015;(December):651-6.

18. Vilte DA, Larzábal M, Cataldi ÁA, Mercado EC. Bovine colostrum contains immunoglobulin G antibodies against intimin, EspA, and EspB and inhibits hemolytic activity mediated by the type three secretion system of attaching and effacing Escherichia coli. Clin Vaccine Immunol. 2008;15(8):1208-13.

19. Srivastava NM, Awasthi S. Breastfeeding practices for newborns among urban poor in Lucknow, northern India: A prospective follow-up study. Clin Epidemiol Glob Heal. 2014;2(2):66-74.

20. Haider R, Rasheed S, Sanghvi TG, Hassan N, Pachon H, Islam S, et al. Breastfeeding in infancy: Identifying the program-relevant issues in Bangladesh. Int Breastfeed J. 2010;5:1-12.

21. Gualu T. Assessment of Knowledge, Attitude and Practice of Post Natal Mothers towards Colostrum Breast Milk in Debre Markos Town Governmental Health Institutions East Gojjam Zone, Amhara Regional State, Ethiopia. Nurs Care Open Access J. 2017;2(2).

22. S. V, M. S, V. S. Assessment of knowledge, attitude and practice of breast feeding among postnatal mothers at Mandya Institute of Medical Sciences, Mandya, India. Int J Contemp Pediatr. 2016;3(2):504-8.

23. Africa WC, Asia S. Social and Behaviour Change Interventions for Promoting Early and Exclusive Breastfeeding, 2015. 2015;(3).

24. FELIX K. Knowledge, Attitudes AND Practices on early breast feeding aming mothers delivering at MOI teaching \& referal hospital in UASIN-GISHU country, KENYA. H60/CTY/PT/27608/2013. 2017;91(May):399-404.

25. Manjura M, Bolesh A, Sisay D, Negash S, Shewasinad S. Assessment of Knowledge, Attitude and Practice Towards Colostrum Feeding Among Antenatal Care Attendant Pregnant Mothers in Mizan Tepi University Teaching Hospital, Bench Maji Zone, SNNPR, South West Ethiopia, 2016/2017 G.C. J Pregnancy Child Heal. 2017;04(05).

26. FELIX K. Knowledge, Attitude,s \& Practices on early breastfeeding among mothers of delivering at MOI teaching \& refferal hospital in Uasin-Gishu country, Kenya. H60/CTY/PT/27608/2013. 2017;91(May):399-404.

27. Gualu T. Assessment of Knowledge, Attitude and Practice of Post Natal Mothers towards Colostrum Breast Milk in Debre Markos Town Governmental Health Institutions East Gojjam Zone, Amhara Regional State, Ethiopia. Nurs Care Open Access J. 2017;2(2).

28. Gizaw AB, Beyene DH, Menji ZA. Magnitude of Pre-Lacteal Feeding Practice and Associ- ated Factors among Mothers having Children Less than 2 Years of Age in Fitche Town, North Showa, Ethiopia. 2018;3:12-9. 
29. Legesse Liben M. Determinants of Early Initiation of Breastfeeding Among Mothers: The Case of Raya Kobo District, Northeast Ethiopia: A Cross-Sectional Study. Int J Nutr Food Sci. 2015;4(3):289.

30. Cherie N. Colostrum Avoidance and Associated Factors Among Mothers of postnatal attendants in northen Ethiopia, 2018. 2018;(July).

31. Weldesamuel GT, Atalay HT, Zemichael TM, Gebre HG, Abraha DG, Amare AK, et al. Colostrum avoidance and associated factors among mothers having children less than 2 years of age in Aksum town, Tigray, Ethiopia: A cross-sectional study 2017. BMC Res Notes. 2018;11(1):1-7.

32. Tewabe T. Timely initiation of breastfeeding and associated factors among mothers in Motta town, East Gojjam zone, Amhara regional state, Ethiopia, 2015: A cross-sectional study. BMC Pregnancy Childbirth. 2016;16(1):1-7.

33. Manjura M, Bolesh A, Sisay D, Negash S, Shewasinad S. Assessment of Knowledge, Attitude and Practice Towards Colostrum Feeding Among Antenatal Care Attendant Pregnant Mothers in Mizan Tepi University Teaching Hospital, Bench Maji Zone, SNNPR, South West Ethiopia, 2016/2017 G.C. J Pregnancy Child Heal. 2017;04(05).

34. Vijayalakshmi P. Knowledge, attitudes, and breast feeding practices of postnatal mothers: A cross sectional survey. 2015;9(4).

35. Dashti M, Scott JA, Edwards CA, Al-sughayer M. Predictors of Breastfeeding Duration among Women in Kuwait: Results of a Prospective Cohort Study. 2014;(February).

36. Gebreyesus H., Girma E. NC. Colostrum Avoidance and Associated Factors Among Mothers of children aged less than 12 months in Kombolcha town. 2017;(2394).

37. Feeding YC, Practices HS. Infant and Young Child Feeding and Health Seeking Practices. 2007; (December).

38. Haider R, Rasheed S, Sanghvi TG, Hassan N, Pachon H, Islam S, et al. Breastfeeding in infancy: Identifying the program-relevant issues in Bangladesh. Int Breastfeed J. 2010;5:1-12.

39. Health E. Nutrition baseline survey report for the NATIONAL NUTRITION PROGRAM of Ethiopia. 2010;

40. Tamiru D, Belachew T, Loha E, Mohammed S. Sub-optimal breastfeeding of infants during the first six months and associated factors in rural communities of Jimma Arjo Woreda, Southwest Ethiopia. BMC Public Health. 2012;12(1):1.

41. Habtemariam Gebreyesus, Eshetu Girma NC. Colostrum avoidance \& associated factors among mothers of children aged less than 12 months in Kombolcha town, south Wollo aone, Ethiopia, Ethiopia, 2017. 2017;(2394).

\section{Figures}


Simple random sampling: $30 \% * 33=11$ Gandas selected (Gandas selected randomly/lottery, study populations assigned proportionally)

(Y/Cebo: $\mathrm{N}=102, \mathrm{n}=33)$; (Bilo: $\mathrm{N}=111, \mathrm{n}=35) ;(\mathrm{G} / \mathrm{Q}$ ora: $\mathrm{N}=234, \mathrm{n}=75)$; (G/Wadessa: $\mathrm{N}=94, \mathrm{n}=30)$;

(Golja: $N=149, n=48) ;(U / Q o r k e: ~ N=143, n=47) ;(M e t i: ~ N=48, n=15) ;(N /$ Warqa: $N=111, n=35)$;

(Amaro: $\mathrm{N}=112, \mathrm{n}=36$ ); (Tule: $\mathrm{N}=164, \mathrm{n}=48$ ); \& (Wadessa: $\mathrm{N}=147, \mathrm{n}=47$ )

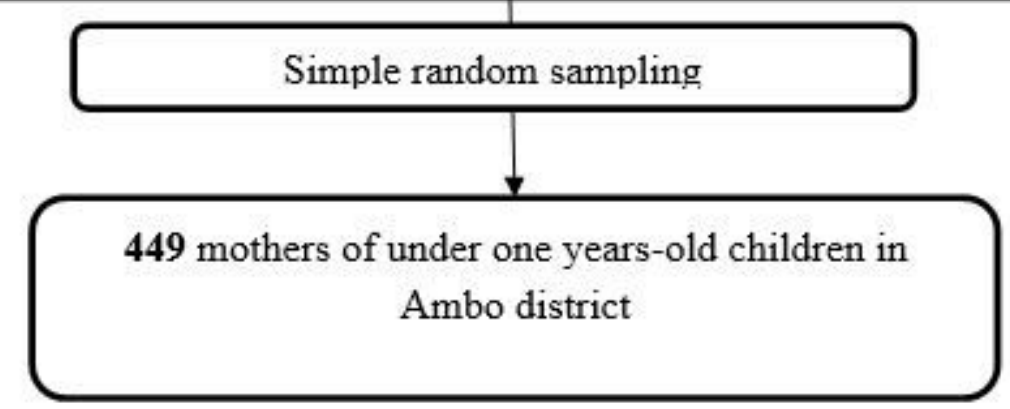

\section{Figure 1}

Schematic presentation of sampling procedure to assess KAP and associated factors towards colostrum feeding among mothers of infants in Ambo district, Ethiopia

\section{Place of birth for current infant in \%}

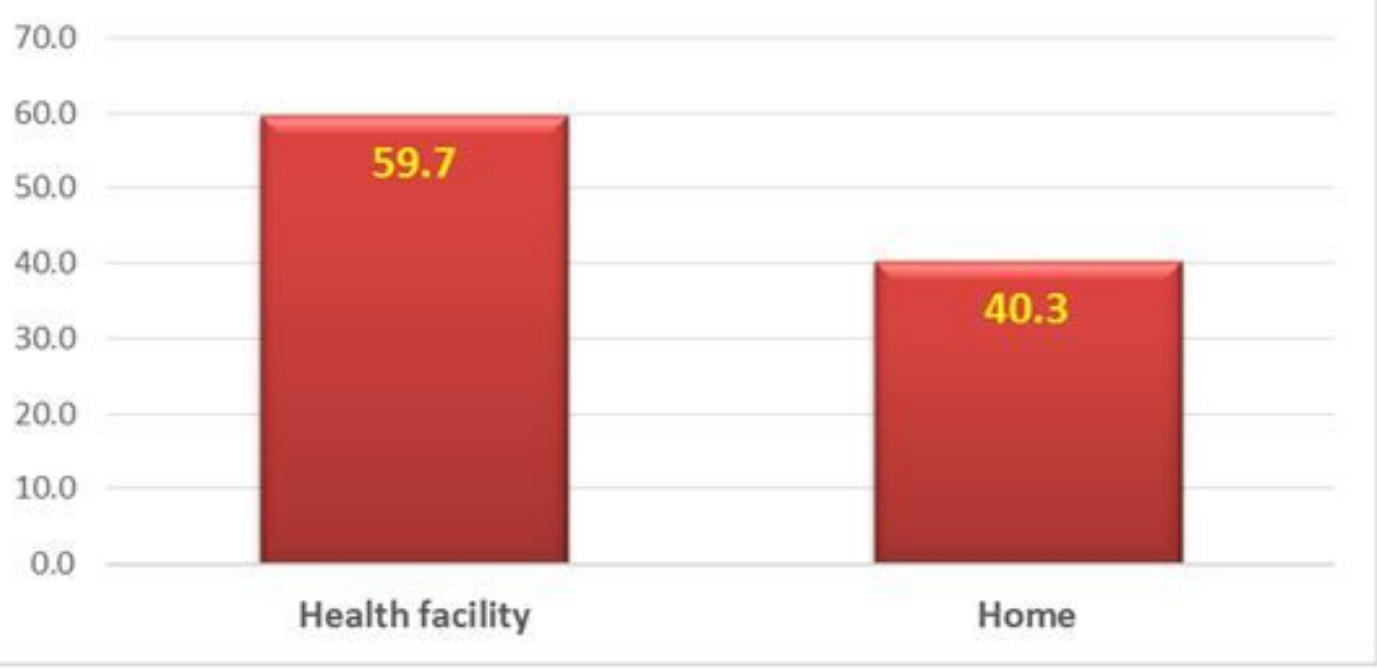

Figure 2 
Maternal distribution based on site of delivery in Ambo district of west Shoa zone Oromia region Ethiopia, 2019

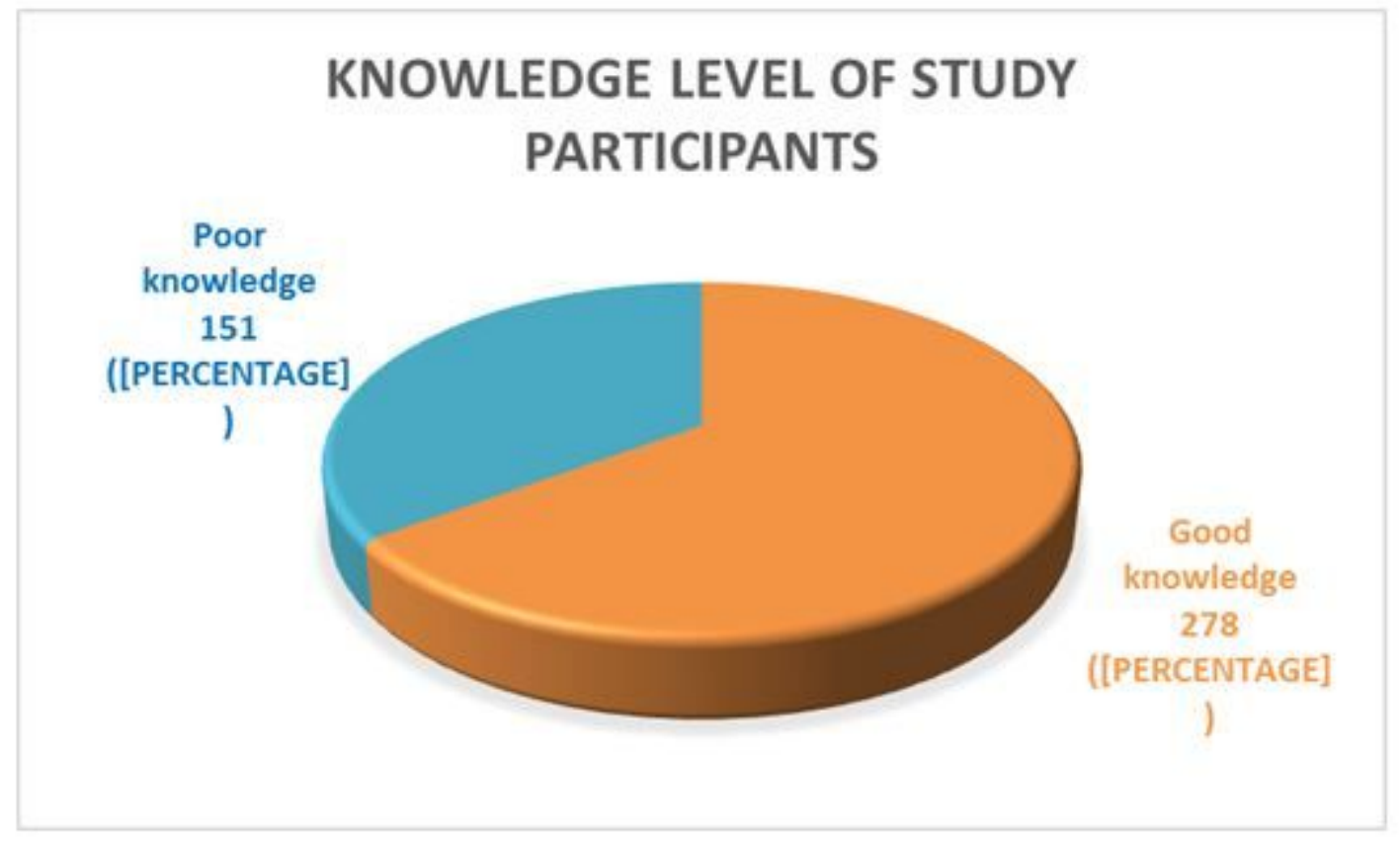

\section{Figure 3}

knowledge of colostrum breast milk among mothers of infants in Ambo district of west Shoa zone, Oromia region, Ethiopia, 2019 